\title{
Perempuan-Perempuan Pemeluk Erat Adat: Studi Etnografi Perempuan Tengger
}

\author{
Sony Sukmawan ${ }^{1}$, Rahmi Febriani ${ }^{2}$ \\ 1,2) Universitas Brawijaya, Jl. Veteran Kota Malang 65145, Indonesia \\ e-mail: ${ }^{1)}$ sony sukmawan@ub.ac.id;
}

\begin{abstract}
Abstrak
Perempuan Tengger meyakini bahwa kepribadian yang mereka miliki merupakan warisan leluhur mereka, Rara Anteng.Keyakinan ini menjadikan perempuan Tengger menjalani kehidupan sehari-hari secara disiplin, penuh kerja keras, namun tetap ikhlas. Ada kepercayaan yang tertanam dalam batin setiap perempuan Tengger bahwa tugas seorang istri adalah mendampingi suami dalam ruang rumah tangga sekaligus ruang kerja. Penelitian interdisipliner ini menggunakan pendekatan etnografi dalam pengumpulan data. Situs penelitian ini di Desa Mororejo, Ngadiwono, Wanamerta, dan Telagosari, Kecamatan Tosari, Kabupaten Pasuruan. Hasil penelitian menunjukkan bahwa Perempuan Tengger memegang peranan yang sangat penting dalam menjaga stabilitas kehidupan rumah tangga, sosio-kultural, dan rutinitas ritual (keagamaan). Dapat dikatakan, perempuan Tengger adalah penjaga stabilitas perekonomian rumah tangga maupun perekonomian lokal sekaligus pemelihara tradisi leluhur Tengger.
\end{abstract}

Kata kunci: Perempuan Tengger; Folklor; Ritual Tengger

\section{Women as The Cultur Embracers: The Etnography Study of Tengger Women}

\begin{abstract}
Tengger women believe that the personality they have is the legacy of their ancestor, Rara Anteng. This belief makes Tengger women live everyday life in a disciplined and sincere manner and full of hard work. There is a belief that is embedded in the mind of every Tengger woman that the duty of a wife is to accompany the husband in the domestic sphere as well as the public sphere. This interdisciplinary research used an ethnographic approach in data collection. The research sites were in Mororejo Village, Ngadiwono, Wanamerta, and Telagosari, Tosari District, in Pasuruan Regency. The results show that Tengger Women play a very important role in maintaining the stability of household life, socio-cultural, and ritual (religious) routines. It can be said that Tengger women are the guardians of the stability of the household economy as well as the local economy while at the same time become the preserver of Tengger ancestral tradition.
\end{abstract}

Keywords: Tengger Women; Folklor; Tengger Ritual

\section{Pendahuluan}

Dinamika pelaksanaan ritual Tengger bisa diibaratkan aliran mata air yang tetap mengalir di antara peredaran dan ketakmenentuan musim. Mata air ini sulit mati karena digerakkan oleh struktur dalam maupun struktur luar kebudayaan Tengger. Struktur dalamnya adalah masyarakat pelaku aktif kebudayaan, sedangkan struktur luarnya adalah aktor antagonis industri-modernisasi yang bernama pariwisata. Tingkat kepercayaan Orang Tengger terhadap adat-ritual sudah sudah sangat laten dan 
mendarah daging. Adat dan tradisi menjadi semacam busana sehari-hari karena tidak kurang dari 18 jenis hajatan ritual dalam tiap tahunnya mereka rayakan. Kokohnya pembatinan (internalisasi) kepercayaan terhadap tradisi inilah yang menjadi jangkar penyeimbang stabilitas raga budaya Tengger dari ombang-ambing jaman dan peradapan. Hal ini tentu menjadi arus angin yang membantu proses penyerbukan bunga-bunga indah budaya. Bagaimanakah antagonista yang bernama modernisasi? Bagaimanakah sosok ini turut andil dalam membangun identitas, kompleksitas, dan ekslusivitas adat dan ritual Tengger? Adalah perempuan Tengger, bagian dari pelaku aktif 'yang pasif' terhadap kebudayaan mereka, turut merasakan dampak kuat pusaran angin perubahan yang diakibatkan oleh modernisasi. Dampak tersebut dirasakan pada hampir seluruh ruang kehidupan keseharian mereka. Namun demikian, yang paling hebat dirasakan adalah dampak terhadap perekonomian. Perempuan Tengger yang pada awalnya banyak meluangkan waktu untuk mencuci, momong anak, memasak dan setelahnya mengirim makan ke ladang, kini harus turut bekerja sepanjang hari membantu para suami mereka mengolah ladang. Artikel ini berupaya mendeskripsikan kaitan ritual adat Tengger terhadap dinamika dunia-kehidupan dan dunia batin perempun Tengger.

\section{Metode Penelitian}

Penelitian interdisipliner ini menggabungkan pendekatan budaya, pendekatan gender, dan folkloristik. Pendekatan etnografi digunakan dalam pengumpulan data berdasarkan pertimbangan bahwa penelitian ini bertujuan mendeskripsikan secara mendalam dan holistik (material dan spiritual) kebu-dayaan perempuan Tengger (sebagai hasil dan proses) sebagaimana adanya (senyatanya) melalui penyajian pandangan hidup, bagaimana mereka berpikir, hidup, berperilaku, berinteraksi dan bekerja-sama (emik) melalui fenomena teramati dalam kehidupan sehari-hari. Penelitian ini dilakukan di Desa Mororejo, Ngadiwono, Wanamerta, dan Telagosari, Kecamatan Tosari, Kabupaten Pasuruan.

Data penelitian ini berupa ekspresi folkloristik yang terwujud dalam ungkapan, tuturan, atau ekspresi lisan (oral), tindak/gerak atau perilaku simbolik. Data tersebut didapatkan dalam konteks upacara ritual, pendarasan mantra, dan tuturan cerita. Data penelitian sebagaimana yang dimaksudkan diperoleh dari pemangku budaya, pelaku/penutur langsung, pegiat seni, atau pemilik tradisi, yaitu dukun, kuncen, sesepuh desa, dan budayawan atau seniman, dan masyarakat kebanyakan yang memenuhi kriteria yang telah ditetapkan. Data penelitian dikumpulkan dengan teknik wawancara tidak terstruktur dan observasi. Setelah terkumpul, data dianalisis secara etnografis, yakni analisis wawancara etnografis, analisis ranah, mengajukan pertanyaan struktural, analisis taksonomi, mengajukan pertanyaan kontras, analisis komponensial, analisis tema kultural, dan menulisetnografi (Spradley, 1997).

\section{Hasil dan Pembahasan \\ Perempuan tengger dalam tradisi lisan}

Perempuan Tengger memegang peranan yang sangat penting dalam menjaga stabilitas kehidupan rumah tangga, sosio-kultural, dan rutinitas ritual (keagamaan). Sejatinya, perempuan Tengger muncul sebagai pribadi 'unik' yang merupakan bagian dari trah perempuan Jawa. Karena itu, dalam meyakini dan menjalankan adat, 
perempuan Tengger tidakakan terlepas dari falsafah hidup seorang Jawa.Hal ini selaras dengan pendapat Yuliati (2011: 105) bahwa masyarakat Tengger sampai sekarang masih memegang teguh nilai-nilai tradisionalnya. Kepercayaan terhadap sosok mitologis perempuan Tengger, yakni Rara Anteng, memberikan kemampuan kepada perempuan Tengger untuk mengeksplorasi diri 'melebihi' batas ke-Jawa-annya. Perempuan Tengger percaya bahwa kepribadian yang dimiliki oleh mereka merupakan warisan sifat dari Rara Anteng selaku nenek moyangnya.

Perempuan Tengger tidak sama dengan perempuan lain. Perempuan Tengger itu kuat, sopan, tekun, dan berani. Jarang sekali melakukan hal-hal yang tidak baik. Ini merupakan cerminan dari sosok Rara Anteng. Selain itu, zaman dahulu maupun sekarang perempuan Tengger pasti suka bekerja. (Ibu Hariati, 48 tahun, Wawancara Mei 2017)

Sosok Rara Anteng dalam legenda suku Tengger memberikan pengaruh yang besar terhadap tindak-tanduk perempuan Tengger. Dalam perspektif mereka, Rara Anteng merupakan sosok wanita yang kuat, tangguh dan sabar. Pemahaman ini mereka dapatkan dari riwayat Rara Anteng dan Jaka Seger beserta ke 25 anaknya. Singkat cerita, Rara Anteng yang merupakan putri dari seorang raja Kerajaan Majapahit harus pergi ke tempat yang lebih aman karena situasi politik di kerajaan sedang kacau saat itu. Tempat pelarian yang dimaksudkan adalah Penanjakan. Sampai suatu waktu, seorang resi yang bernama Resi Dadap Putih mengangkatnya sebagai anak.

Dampak dari kekacauan yang terjadi di Majapahit sampai pula ke Kediri. Jaka Seger yang merupakan putra dari seorang Brahmana juga terpaksa 'minggat' dari tanah kelahirannya ke desa Kedawung. Selain itu, Jaka Seger memiliki tujuan lain yakni mencari pamannya yang tinggal di dekat Gunung Bromo, tepatnya di Penanjakan. Maka, di tempat itulah Rara Anteng dan Jaka Seger bertemu sampai akhirnya Resi Dadap Putih menikahkan keduanya. Namun, penikahan mereka yang sudah menginjak usia sewindutak kunjung jua dikaruniai anak. Akhirnya, mereka berdua memutuskan untuk bersemedi selama enam tahun lamanya hingga pada akhirnya dikaruniai anak sebanyak 25 orang.

Selama berkeluarga, Rara Anteng dan Jaka Seger hidup berdikari untuk memenuhi kebutuhan hidupnya dengan berladang. Pekerjaan Rara Anteng tidak terbatas hanya pada pekerjaan dapur. Akan tetapi, Rara Anteng selalu membantu Jaka Seger dalam menggarap ladangnya. Tidak hanya itu, seluruh anaknya juga terbiasa membantu kedua orangtuanya berladang. Maka, hal ini menjadi dogma bagi masyarakat Tengger, khususnya perempuan, yang harus mereka pegang teguh agar citra seorang perempuan Tengger yang telah diwariskan oleh nenek moyang mereka tetap bertahan dalam semua jaman. Tindak-tanduk dan tindak-tutur perempuan Tengger masa kini adalah representasi dari kepribadian sosok Rara Anteng di masa silam.

Selain dalam narasi legenda, perempuan Tengger juga terepresentasi dalam narasi mitos. Dalam mitos Tengger kehadiran danyang-danyang perempuan diyakini menempati tiga ruang, yakni ruang moncopat, lokal khusus, dan local desa. Yang menempati ruang moncopat, lokal, dan desa masing-masing adalah danyang moncopat, danyang lokal, dan danyang desa. Danyang moncopat adalah (Kaki) Nini Nyokro Buono Kaping Sewelas. Danyang lokal khusus adalah Nini Towok sebagai danyang rumah, Nini Sorosoti sebagai danyang dapur, Nini Kolo 
Kancing sebagai danyang pintu, dan Nini Kolo Kenjer sebagai danyang jalan. Nini Towok, danyang pawon 'dapur'; Nini Soro Soti, danyang geni 'api'; Nini Kolo Kancing, danyang lawang 'pintu'; Nini Kolo Jenger, danyang jogan 'lantai rumah'; dan Nini Kolo Kenjer, danyang dalan 'jalan'. Danyang perempuan desa-desa Tengger di antaranya adalah Nini Sundari (danyang desa Argosari), Nyai Juminah (danyang desa Padakaya), Mbah Srintil (danyang desa Kaliteja), Mbah Mauni (Mororejo), Nini Purwosari, Nini Mergosari, dan Nini Sumbersari (Sukmawan dkk., 2017:363).

\section{Perempuan tengger sebagai perempuan pekerja keras}

Aktivitas yang dijalani oleh masyarakat Tengger pada umumnya tidak jauh berbeda dengan masyarakat (Jawa) lainnya di luar suku Tengger yang bermata pencaharian sebagai petani. Namun, masyarakat Tengger memiliki sistem adat yang berbeda, yakni bersendi kepada keyakinan agama Tengger. Kepercayaan terhadap Dewata yang menjadi dasar keyakinan untuk senantiasa mempertahankan tradisi, sangat berpengaruh terhadap rutinitas keseharian yang dijalani. Sebagai masyarakat yang taat terhadap adat, perempuan Tengger menjadi 'kunci' bagi tradisi sehingga secara turun-temurun selalu terlaksanadan terjaga secara berkesinambungan. Di dalam rumah tangga atau keluarga, perempuan (istri) bertanggung jawab untuk mengatur dan mengurus segala keperluan yang berkaitan dengan kerumahtanggaan.

Perempuan Tengger sebetulnya sangat menunjang suami. Peranan suami dalam rumah tangga hanya untuk bekerja dari pagi sampai sore, tidak membantu pekerjaan rumah tangga. Walaupun seorang perempuan itu berprofesi sebagai pegawai yang biasanya bekerja dari pagi sampai siang, setelah pekerjaan itu selesai, maka akan melanjutkan pekerjaannya yang tertunda di ladang. Jadi, tidak ada waktu untuk diam atau leha-leha saja. (Ibu Hariati, 48 tahun, Wawancara 1 Mei 2017)

Perempuan Tengger telah terbiasa menjalani rutinitas harian dengan bangun lebih pagi dan memulai pekerjaan lebih awal daripada laki-laki. Aktivitas perempuan Tengger dimulai sejak bangun tidur sekitar pukul 04.00 WIB dengan kegiatan membersihkan diri seperti mencuci muka dan menggosok gigi. Setelah diri dirasa bersih, aktivitas akan dilanjutkan dengan bersih-bersih rumah seperti menyapu, mencuci piring, dan mencuci baju. Selanjutnya, memasak dan menyiapkan makan untuk suami serta anak. Setelah pekerjaan di rumah selesai dan anak berangkat ke sekolah, perempuan Tengger akan pergi ke ladang sekitar pukul 08.00 WIB untuk menyusul sekaligus membantu pekerjaan suami hingga pukul 15.00 WIB. Setibanya di rumah, perempuan Tengger akan membersihkan diri atau mandi. Lalu, memasak dan menyiapkan lagi makan untuk suami serta anak. Tidak jarang, yang dimasak adalah sayuran yang sebelumnya dibawa dari ladang. Lalu, aktivitas akan dilanjutkan kembali untuk menyelesaikan pekerjaan yang tertunda sewaktu pagi. Setelah pekerjaan di rumah selesai, para anggota keluarga akan berkumpul di ruang keluarga untuk sekadar berbincang-bincang atau menonton televisi bersama hingga tiba saatnya waktu istirahat sekitar pukul 21.00 WIB. 
Perempuan Tengger di masa kini mulai banyak yang berprofesi sebagai pegawai, baik itu di sekolah sebagai guru maupun staf di instansi pemerintahan lainnya. Hal tersebut dikarenakan kesadaran akan pentingnya pendidikan bagi kehidupan di masa kini dan mendatang semakin meningkat. Pendidikan dianggap sebagai sarana untuk membuka wawasan berpikir mengenai ilmu yang tidak didapatkan di rumah atau lingkungan. Maka, bersekolah adalah jalan yang tepat untuk mendapatkan pendidikan secara formal. Di kecamatan Tosari, sudah banyak para lbu yang peduli terhadap pendidikan anak dan tak sedikit yang melanjutkan pendidikan ke jenjang yang lebih tinggi bahkan sampai ke perguruan tinggi. Akses untuk mendapatkan pendidikan yang layak semakin dipermudah oleh pemerintah. Adanya program beasiswa bagi siswa berprestasi merupakan salah satu upaya pemerintah agar warganya mampu selangkah lebih maju dalam hal pendidikan. Namun, bukan perempuan Tengger namanya walaupun mengemban tanggung jawab sebagai pegawai di kantoran jika tidak menunaikan tugasnya sebagai seorang istri, yakni; pergi berladang. Setelah usai pekerjaan di kantor sekitar pukul $13.00 \mathrm{WIB}$, perempuan Tengger akan menyusul suaminya yang masih bekerja di ladang sampai pekerjaan hari itu dirasa cukup. Ketika kembali ke rumah, akan melakukan aktivitas yang sama seperti perempuan Tengger pada umumnya sampai tiba saat untuk beristirahat.

Tanpa mengenal lelah, aktivitas perempuan Tengger tersebut dilakukan setiap hari secara terus-menerus. Biasanya serangkaian aktivitas yang dipaparkan di atas dilakukan oleh seorang perempuan yang sudah bersuami. Bagi perempuan remaja, peranannya dalam rumah tangga adalah membantu Sang lbu untuk menyelesaikan pekerjaan-pekerjaan tersebut, termasuk pekerjaan di ladang. Apabila si Anak sekolah, biasanya sepulang dari sekolah akan menyusul orang tuanya ke ladang sambil membawa bekal makan untuk makan siang. Namun, apabila sudah bersuami, maka akan melakukan aktivitas yang sama seperti yang biasa ibunya lakukan. Yang berbeda adalah pergi ke ladang dengan tujuan utamanya tidak lagi membantu Sang lbu, melainkan membantu suami untuk menggarap ladangnya.

Ada kepercayaan yang tertanam dalam batin setiap perempuan Tengger, bahwa tugas seorang istri adalah mendampingi suami. Mendampingi suami bukan sekadar menemani tetapi juga dimaknai mengurus diri, mengatur keperluan dan meringankan pekerjaan suami. Secara sadar diakui bahwa dalam memikul pekerjaan, tanggung jawab seorang perempuan Tengger jauh lebih berat dibandingkan dengan tanggung jawab seorang laki-laki. Namun, sedikitpun tidak ada rasa keberatan dan jauh dari pikiran untuk berkeluh kesah. Semua ini dilakukan samata-mata demi suatu tujuan yang mulia, yakni kesejahteraan keluarga (Setiawan, 141: 2008). Terlepas dari itu semua, rutinitas keseharian perempuan Tengger memang merupakan kebiasaan (adat) yang selalu diwariskan secara turun-temurun. Adanya kebiasaan tersebut, menjadikan beban yang dipikul tak lagi menjelma sebagai sebuah pikulan melainkan sebuah keharusan (takdir) yang semestinya dijalani.

Pembedaan peran antara perempuan dengan laki-laki umumnya ada tiga, yaitu kegiatan produktif, kegiatan reproduktif dan kegiatan sosial (Yuliati, 2011: 165). Namun, dari ketiga jenis kegiatan tersebut yang bersinggungan secara langsung dengan bagian internal rumah tangga yaitu kegiatan produktif dan reproduktif. Kegiatan produktif adalah segala kegiatan yang mampu menghasilkan keuntungan material baik itu berupa uang secara langsung maupun barang yang kemudian bisa 'diuangkan'. Sedangkan, kegiatan 
reproduktif adalah kegiatan yang berkaitan dengan kelangsungan kehidupan dalam rumah tangga. Lebih pada merawat ruang dan anggota keluarga seperti memasak, mencuci, menyapu, dan sebagainya.

Kegiatan produktif lazim dilakukan oleh laki-laki dan kegiatan reproduktif menjadi tanggung jawab seorang perempuan. Di Tengger, prinsip tersebut tetap berlaku sesuai tempatnya. Di mana laki-laki memiliki peranan untuk menjalani kegiatan produktif di ladang dan perempuan menjalani tanggung jawabnya untuk menyelesaikan kegiatan reproduktif di rumah. Namun, sekali lagi, perempuan Tengger menunjukkan peranan aktifnya dalam bidang pekerjaan. Sesuai dengan apa yang telah dipaparkan pada subbab sebelumnya, bahwa ruang gerak perempuan Tengger tidak terkotakkan hanya pada ruang rumah tangga. Akan tetapi, lebih luas dari itu, keberadaan perempuan Tengger dianggap penting untuk menunjang keberhasilan pekerjaan laki-laki di ladang (produktif).

Sejak dahulu, perempuan Tengger terbiasa pergi ke ladang untuk membantu suami dalam menggarap ladangnya. Tidak hanya "ngantar" makanan, tetapi turut bekerja secara produktif seperti halnya laki-laki. Dalam hal ini, tidak ada pembagian kerja secara khusus yang membedakan antara laki-laki dengan perempuan. Perempuan akan melakukan segala pekerjaan yang memang sedang dibutuhkan di ladang. Ngobat, mencangkul, tandur, menanam, memanen, semuanya tanpa kecuali, perempuan Tengger dengan piawai dan telaten akan menyelesaikan pekerjaan demi pekerjaan tersebut. Yang menarik adalah tidak ada pembelajaran secara khusus mengenai ilmu bercocok tanam, semua mereka dapatkan secara otodidak, lisan, dan pengamatan. Mitchell dkk., (2000) mengungkapkan bahwa pemahaman masyarakat tradisional tentang sistem (pengelolaan) alam biasanya diwariskan secara lisan serta tidak dapat dijelaskan melalui istilah-istilah ilmiah. Hal ini menjadi wajar kiranya sebab masyarakat Tengger dalam kehidupannya memang sangat dekat dengan alam. Berawal dari pengamatan dan berbekal insting serta pengalaman, perempuan Tengger dengan berani dan optimis turut berkecimpung langsung dalam menopang keberhasilan bertani di ladang.

Dalam hal bertani, sebetulnya teknik bertani yang diterapkan oleh masyarakat Tengger masih dilakukan dengan cara yang cukup sederhana. Hal yang memengaruhi salahsatunya adalah jenis tanaman yang ditanam. Jenis tanaman tersebut biasanya berupa palawija (jagung, ucet), palakapendem (kentang, wortel), palakasimpar (ketela) juga jenis sayuran lainnya seperti kubis, daun bawang, lombok terong dan sebagainya. Karena jenis sayuran yang ditanam memiliki pengerjaan dan perawatan yang tidak jauh berbeda, maka teknik bertani yang dilakukanpun cukup sederhana. Contohnya, dalam pembuatan patar atau lubang sebagai tempat menaruh bibit, cukup dibuat lubang kecil lalu bibit ditaruh dalam lubang tersebut dan ditutup kembali dengan tanah. Selanjutnya akandilakukan proses perawatan, salahsatunya adalah proses ngrumati. Kemudian akan dilakukan penyemprotan menggunakan pestisida.

Tidak ada permasalahan yang cukup berarti dalam bertani mengenai gangguan hama, biasanya jenis hama yang cukup mengganggu berupa ulat. Hal ini, bisa ditangani dengan melakukan penyemprotan menggunakan pestisida. Akan tetapi, pada tanaman kentang memang memerlukan perhatian khusus, sebab terlambat penyemprotan barang sehari saja biasanya daun kentang akan menguning lantas mengering. Jika demikian, tanaman kentang tidak akan berumur panjang dan dapat dipastikan akan mengalami gagal panen. Terlepas dari itu semua, tanaman kentang adalah jenis sayuran yang 
mampu tumbuh dengan baik saat ladang tertutup abu vulkanik akibat dari letusan gunung Bromo. Karena itu, tanaman kentang merupakan salah satu jenis sayuran yang banyak ditanam oleh masyarakat Tengger.

Perempuan Tengger yang sudah menikah dan memiliki anak, biasanya akan membawa anak tersebut ke ladang untuk turut membantu pekerjaan orangtuanya. Sejak usia 5 tahun, anak sudah mulai diperkenalkan dengan dunia-kerja di ladang. Bahkan, beberapa orangtua memomong anak-sekaligus bekerja-ketika usia anak baru menginjak 3 bulan. Hal ini dilakukan untuk meminimalkan waktu libur ke ladang pasca melahirkan. Perempuan Tengger sangat menyadari peranan dan kedudukannya sebagai seorang istri, jika terlalu lama tidak membantu pekerjaan suami di ladang tentu akan sangat memengaruhi keberhasilan di musim panen saat itu. Meskipun terdapat opsi lain, yakni meminta tenaga buruh tani untuk membantu menyelesaikan pekerjaan. $\mathrm{Hal}$ itu tentu akan menjadi pilihan yang sulit, karena tenaga buruh harus dibayar dan pengeluaran uang akan jauh lebih banyak sedangkan kebutuhan kian hari kian meningkat. Maka, satu-satunya pilihan adalah mempersingkat waktu libur ke ladang pasca melahirkan. Bukan tanpa alasan, keyakinan untuk senantiasa mempertahankan tradisi di tengah arus jaman yang cenderung 'meninggalkan' tradisi menjadi tantangan tersendiri. Intensitas ritual keagamaan yang dijalani dengan serangkaian sesaji yang digunakan nampaknya menjadi alasan kuat bagi para perempuan Tengger untuk turut 'menutupi' perekonomian keluarga, agar tak pernah alpa dalam pelaksanaan ritual. Sebab, mereka meyakini bahwa jika tidak melangsungkan salah satu ritual, Dewata akan murka dan manusia sendiri yang akan menanggung kepedihan akibatnya. Lebih jauh lagi, dengan melaksanakan ritual, mereka merasakan ketenangan dalam menjalani kehidupan sehari-hari, termasuk melaksanakan pekerjaan rutin di ladang. Sukmawan (2015) menegaskan bahwa kenyamanan bekerja secara harmonis dengan alam didapati dan dirasakan oleh masyarakat Jawa, termasuk masyarakat Tengger, setelah melakukan ritual membina hubungan dengan roh leluhur melalui penyiapan sesaji dan selametan.

Selain kebutuhan sehari-hari dan kebutuhan selamatan, kebutuhan lainnya seperti biaya sekolah anak-anak juga menjadi pilihan logis bagi perempuan Tengger untuk turut menopang perekonomian keluarga. Karena itu, perempuan Tengger akan bekerja di ladang dengan berangkat pagi setelah selesai pekerjaan rumah dan akan selesai pada sore hari menjelang malam. Jika biasanya selesai bekerja pada pukul 15.00 WIB maka mereka akan menambah jam kerja hingga pukul 17.00 WIB agar mendapatkan dua hari kerja dan dua kali upah (pekerjaan cepat selesai) untuk menutupi semua kebutuhan. Kebiasaan lembur seperti ini hanya dilakukan oleh beberapa perempuan Tengger pada beberapa daerah, misalnya di daerah Wanamerta dan Wanakitri.

\section{Perempuan tengger sebagai pemelihara adat}

Tengger merupakan suku yang memiliki tingkat kepercayaan terhadap adat-ritual yang sudah laten dan mendarah daging. Setiap tahunnya lebih dari 18 ritual yang mereka rayakan. Yuliati (2015) mengklasifikasikan ritual tersebut ke dalam tiga kelompok: (i) ritual yang berhubungan dengan kehidupan bermasyarakat: Hari Raya Karo, Pujan Kapat, Pujan Kapitu, Pujan Kawolu, Pujan Kasanga, Hari Raya Yadnya Kasada, dan Unan-unan; (ii) ritual adat yang berhubungan dengan siklus kehidupan 
seseorang: ritual Sayud (upacara usia kehamilan tujuh bulan), ritual Cuplak Puseur, ritual Tugel Kuncung atau Tugel Gembok, Walagara, dan Entas-entas; (iii) ritual yang berkaitan dengan kegiatan usaha tani: leliwet. Dari sekian banyak ritual yang rutin dirayakan oleh masyarakat Tengger, beberapa di antaranya dikhususkan untuk perempuan, yaitu ritual sayud (mitoni), ritual babaran pagenepan dan ritual amongamong. Sayut adalah upacara (selamatan) yang diadakan ketika bayi yang masih dalam kandungan berumur tujuh bulan, maksud dari upacara sayut adalah agar bayi lahir dengan lancer dan selamat (Sutarto, 2008:237). Selanjutnya, ritual among-among adalah salah satu rangkaian upacara kelahiran yang diselenggarakan ketika bayi berumur 44 hari. Maksud dari upacara ini adalah agar bayi terbebas dari gangguan roh jahat. Orang Tengger percaya apabila tidak mengadakan selamatan dan tidak memberikan sajian, anak cucu mereka akan diganggu oleh roh-roh jahat (Sutarto, 2008:4).

Sementara itu, ritual yang harus diikuti oleh perempuan Tengger yaitu Jumat Legi, Barikan, Pujan, Kasada, dan Karo.Larangan mengikuti ritual bagi perempuan Tengger hanya jika sedang dalam masa juntaka (menstruasi), itupun jika pelaksanaannya di pura, apabila pelaksanaan ritual dilakukan di luar pura maka perempuan yang sedang dalam masa cuntaka tetap boleh mengikuti. Pelaksanaan ritual muskil terlaksana jika perempuan tidak turut terlibat, perempuan selalu dan pasti hadir. Dalam hal ini, perempuan menjadi sangat penting peranannya sebagai 'penyedia' unsur vital ritual yakni sesesaji. Tujuan (se)sesaji itu sendiri adalah sebagai sarana yang akan dihaturkan kepada roh leluhur sekaligus sarana untuk memberitahu para leluhur tentang suatu ritual yang akan dilaksanakan. Dalam sesaji terdapat berbagai macam unsur diantaranya adalah pisang ayu, jambe ayu, beras fitrah, dan lain sebagainya. Termasuk di dalamnya terdapat jajanan (kue) yang wajib ada dalam sesesaji yaitu, kue pasung sebagai simbol kelamin laki-laki, kue pepes sebagai simbol kelamin perempuan, juadah putih sebagai simbol Bapak Hutan, juadah abang adalah simbol Ibu Hutan, juadah ireng adalah simbol Hutan, dan tetelan sebagai simbol kerekatan dalam rumah tangga.

Mbok Dukun yang didampingi oleh pemangku adat lainnya yaitu Mbok Legen. Legen adalah pembantu dukun Tengger yang bertugas mempersiapkan keperluan atau sajian yang terkait dengan kegiatan upacara. la tidak perlu menghafal mantra-mantra, tetapi harus terampil mempersiapkan peralatan upacara, termasuk menyiapkan api untuk kepentingan upacara (Sutarto, 2008:93). Mbok legen adalah isteri Legen yang secara faktual lebih banyak berperan dalam penyiapan sesaji. Selain Mbok legen, yang membantu Mbok dukun adalah Mbok Sepuh dan Mbok Sanggar. Mereka bertanggung jawab untuk membuat, menyusun dan menata setiap sesaji dengan baik tanpa ada kekeliruan. Pembuatan sesaji ini akan dilakukan dengan melakukan pembagian tugas, misal pembuatan kue pasung dilaksanakan di rumah Mbok Dukun, juadah di rumah Mbok Legen, begitupun dengan sesaji yang lainnya. Menjelang penyusunan, sesaji yang dibuat di masing-masing rumah tersebut akan dibawa menuju rumah Mbok dukun untuk disusun dan ditata dengan baik. Tidak hanya rapi tapi sesaji yang terusun harus tepat tata letaknya.

Setiap ritual yang dilaksanakan, baik itu ritual besar maupun kecil, perempuan bertanggung jawab untuk menggalang keguyuban dan kebersamaan, mempersiapkan semua sesaji yang diperlukan, membantu pelaksanaaan tahapan demi tahapan ritual, hingga membereskan segala sesuatu seusai pelaksanaan ritual. Atas dasar ini, 
perempuan memiliki peranan yang sangat penting dalam tatanan kehidupan masyarakat Tengger. Itu mengapa, tanpa adanya perempuan kehidupan dalam rumah tangga, kehidupan sosial masyarakat, dan pelaksanaan ritual keagamaan akan sangat sukar mampu terlaksana dengan baik. Selama ini, perempuanlah yang menjadi penentu keberhasilan dari terlaksananya ritual demi ritual.

\section{Ritual sebagai wadah sosialisasi dan ruang eksistensi perempuan tengger}

Ritual yang dilaksanakan oleh masyarakat Tengger tak terlepas pula dari peranan seorang perempuan. Dalam pelaksanaannya, perempuan akan menjadi lebih sibuk untuk mengurus dan mengatur jalannya ritual. Oleh sebab itu, kaum perempuan akan berkumpul guna mempersiapkan segala keperluan yang akan digunakan saat ritual berlangsung. Dalam ritual (hajat) besar, para tetangga khususnya kaum perempuan akan diberi tahu oleh yang punya hajat satu bulan atau bahkan tiga bulan sebelum hajat itu dilaksanakan. Masyarakat Tengger lebih sering menggunakan Balai Desa sebagai tempat pelaksanaan hajat, khususnya untuk acara pernikahan. Karena itu, tujuh hari sebelum hajat itu berlangsung, kegiatan di Balai Desa sudah mulai ramai. Para perempuan akan berkumpul dan saling bekerja sama untuk menyelesaikan setiap pekerjaan. Perkumpulan perempuan tersebut disebut sebagai Biodoatau bethek. (sinoman bagi laki-laki). Biodo atau bethek dan sinoman adalah warga yang terlinat dalam kegiatan tolong-menolong dalam rangka merayakan suatu hajat, seperti pesta kelahiran, perkawinan, dan hajat lainnya (Sutarto, 2008: 13). Dengan berlandaskan prinsip gotong royong, Ketua Biodo dibagi ke dalam beberapa bagian, yakni: ketua yang bertanggung jawab dalam pembuatan kue, menanak nasi dan memasak lauk.

Melalui perkumpulan dalam suatu wadah bernama Biodo ini, kesempatan untuk bersosialisasi bagi perempuan Tengger semakin terbuka. Pasalnya, para perempuan akan duduk semeja bersama untuk menyelesaikan tugasnya masing-masing baik itu membuat kue, menanak nasi atau memasak lauk. Di sela pekerjaan, biasanya akan dimanfaatkan untuk saling bertukar cerita mengenai keadaan anak-anak, pendidikan, pekerjaan di ladang, dan sebagainya. Maka, melalui perkumpulan ini hubungan antar perempuan Tengger, lebih jauh lagi adalah hubungan antar keluarga di suku Tengger menjadi lebih rukun dan harmonis. Itu mengapa, di Tengger jarang sekali terjadi perselisihan apalagi pertikaian yang melibatkan fisik yang akan mengancam lunturnya nilai kerukunan serta keharmonisan tersebut.

Ritual membuka jalan bagi perempuan Tengger untuk saling membuka diri dan memahami satu sama lain melalui ruang bernama sosialisasi dalam Biodo. Padatnya aktivitas di rumah dan di ladang memberikan peluang sangat kecil bagi para perempuan untuk duduk bersama dan saling beriteraksi dalam waktu yang lama. Maka, dengan adanya ritual dapat membuka ruang dan kesempatan itu. Dari sinilah, perempuan Tengger banyak belajar tentang segala hal yang sifatnya modern. Seperti halnya pendidikan yang tak cukup didapatkan di rumah saja, bahwa anak harus sekolah dan bahwa pendidikan juga penting bagi perempuan. Betapa ritual telah memberikan implikasi yang sangat besar terhadap pola pikir perempuan Tengger. Aktivitas Ritual, baik saat persiapan, pelaksanaan, hingga pascapelaksanaan secara nyata menjadi ruang penegas pentingnya eksistensi perempuan Tengger dalam menjaga tradisi sekaligus memamahi, mengikuti arus, dan menegosiasi modernisasi. Modernisasi yang hadir dalam ruang sakral ritual atau sebaliknya, ruang kecil ritual yang dibingkai oleh 
ruang besar modernisasi, bagaimanapun telah membangkitkan kesadaran perempuan Tengger tentang kemajuan zaman dengan kompleksitas permasalahannya. Untuk kesekian kali, eksistensi (kearifan) perempuan Tengger ditempa dan diuji.

\section{Kesimpulan}

Perempuan Tengger percaya bahwa kepribadian yang mereka miliki adalah warisan sifat Rara Anteng. Perilaku perempuan Tengger masa kini adalah representasi dari kepribadian Rara Anteng pada masa lalu. Kepercayaan terhadap Rara Anteng memberikan keyakinan sekaligus kemampuan kepada perempuan Tengger menjalani kehidupan sehari-hari secara ikhlas. Ada kepercayaan yang tertanam dalam batin setiap perempuan Tengger bahwa tugas seorang istri adalah mendampingi suami. Mendampingi suami bukan sekadar menemani tetapi juga dimaknai mengurus diri, mengatur keperluan dan meringankan pekerjaan suami.

Di luar tanggung jawab keluarga, tanggung jawab adat juga sedia mereka lakukan. Khusus perempuan yang menempati posisi kultural sebagai istri dukun dan asisten dukun, kemampuan manajerial dalam ritual adalah tanggung jawab tambahan. Kemampuan manajerial tersebut adalah menggalang keguyuban dan kebersamaan, mempersiapkan semua sesaji yang diperlukan, membantu palaksanaaan tahapan demi tahapan ritual, hingga membereskan segala sesuatu seusai pelaksanaan ritual. Institusi adat biodo atau bethek menjadi sarana dan wadah membina kerukunan, keguyuban, dan harmoni sosial di antara mereka.

\section{Daftar Pustaka}

Mitchell, B. dkk. (2000). Pengelolaan Sumberdaya dan Lingkungan. Yogjakarta: Gajah Mada University Press.

Setiawan, I. (2008). Perempuan di Balik Kabut Bromo: Membaca Peran Aktif Perempuan Tengger dalam Kehidupan Rumah Tangga dan Masyarakat. Humaniora, Vol 20, No 2, hlm. 136-148.

Spradley, J. (1997). Metode Etnografi. Diterjemahkan oleh Misbah Zulfa Elizabet. Yogyakarta: Tiara Wacana Yogya.

Sukmawan, S. (2015). Apokaliptisme dalam Dongeng-dongeng Nusantara. Penelitian sumber dana BOPTN tahun 2015. Fakultas IImu Budaya. Tidak dipublikasikan.

Sukmawan, S. dkk. (2017). Perempuan dalam Folklor Tengger. Prosiding Seminar Internasional Bahasa dan Pendidikan I, STKIP PGRI Pasuruan, 6-7 September.

Sutarto, A. (2008). Kamus Budaya dan Religi Tengger. Jember: Lemlit Universitas Jember.

Yuliati, Y. (2011). Perubahan Ekologis dan Strategi Adaptasi Masyarakat di Wilayah Pegunungan Tengger: Suatu Kajian Gender dan Lingkungan. Malang: UB Press. 